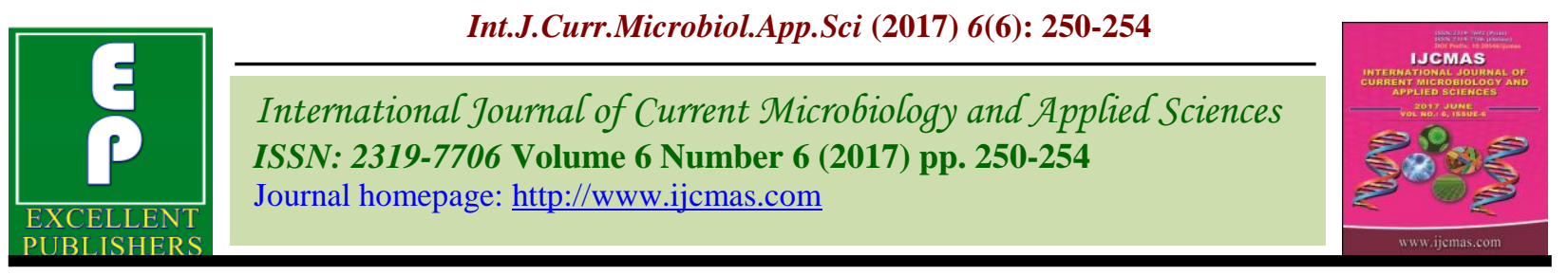

Original Research Article

https://doi.org/10.20546/ijcmas.2017.606.030

\title{
Response of Biochemical Aspects on the Success of Various Propagation Methods in Annual Moringa cv.PKM1
}

\author{
G. Priyadharshini and P. Irene Vethamoni* \\ Department of Vegetable Crops, HC \& RI, \\ Tamil Nadu Agricultural College, Coimbatore-3, Tamil Nadu, India \\ *Corresponding author
}

\begin{abstract}
A B S T R A C T
Keywords

Annual moringa,

Perennial

rootstocks, Scion,

Air layering,

Grafting,

Graft success

Article Info

Accepted:

04 May 2017

Available Online:

10 June 2017

An investigation was carried out to find the role of physiological and biochemical factors in the success of different propagation methods of annual Moringa cv.PKM 1 with respect to root initiation, growth and graft compatibility. The biochemical factors viz., orthodihydroxy phenol content, total phenol, peroxidase activity, catalase activity, total carbohydrate, total nitrogen, starch content, and $\mathrm{C} / \mathrm{N}$ ratio were assessed in the different propagation materials viz., limb cuttings, air layering, grafts of annual Moringa cv.PKM 1 scion with Moolanur Moringa rootstock and Karumbu Moringa rootstock and seedling of annual Moringa cv.PKM 1. Lowest content of ortho dihydroxy phenol, total phenol, with highest peroxidase activity, catalase activity, carbohydrate, starch and nitrogen content were noticed in the grafts with perennial Moolanur Moringa rootstock and annual Moringa cv.PKM 1 scion followed by graft with perennial Karumbu Moringa rootstock with annual Moringa cv.PKM 1 scion which favoured highest success in terms of compatibility than other propagation methods.
\end{abstract}

\section{Introduction}

India is the largest producer of Moringa with an annual production of 1.1 to 1.3 million tonnes of tender fruits from an area of 38.000 ha (Anonymous, 2006). Among the states Andhra Pradesh leads in both area and production $(15,665$ ha) followed by Karnataka (10,280 ha) and Tamil Nadu (7,408 ha). In other states, it occupies an area of 4,613 ha. Tamil Nadu is the pioneering state as it has varied genotypes from diversified geographical areas, as well as introduction from Sri Lanka. Moringa is a fast growing, drought tolerant and compatible tree to varied ecosystems and farming systems.
The perennial Moringa is evergreen and can tolerate drought conditions. In general it is propagated by limb cuttings. But annual Moringa cv. PKM 1 is being propagated through seeds. To assess the rooting efficiency of different propagation methods viz., grafting, air layering, cuttings and seedlings physiological and biochemical aspects were studied.

\section{Materials and Methods}

The graft combinations with perennial Moolanur Moringa rootstocks and annual 
Moringa cv. PKM 1 scion(T4), Karumbu Moringa rootstock with annual Moringa cv. PKM 1 scion(T5), limb cuttings(T1), air layering(T2) and seedlings of PKM 1 Moringa(T3) were utilized for the study to assess the best method of propagation. The biochemical aspects viz., Ortho-dihydroxy phenol, total phenol, peroxidase (PO), catalase, starch, total carbohydrate, total nitrogen, $\mathrm{C} / \mathrm{N}$ ratio were analysed in $\mathrm{CRD}$.

\section{Results and Discussion}

\section{OD phenol}

The data on OD phenol content revealed significant effects with different method of propagation (Table 1). Among different methods of propagation, graft with Moolanur Moringa rootstocks and annual Moringa cv.PKM 1 scion (T3) recorded lowest OD phenol content of $2.68 \mathrm{mg}$ g-1 followed by graft with Karumbu Moringa rootstocks in annual Moringa cv.PKM 1 scion (T4) with $2.82 \mathrm{mg} \mathrm{g}^{-1}$. Highest OD phenol content was registered in limb cuttings of annual Moringa (T1) with $4.45 \mathrm{mg}$ g-1. Highest OD phenol content might be the reason for highest success rate of grafting in terms of graft union and rooting of grafts. The role of phenolic compounds in the regulation of growth and development of plants has been emphasized by many workers. It has long been recognised that the phenolic compounds, which play a vital role in the rooting of plants, are synthesised in leaves and translocated to the base resulting in rooting (Hess, 1962). The concept put forth by Nanda et al., (1974) indicated that phenols at high concentration induced callus formation and the auxins at high concentration induced roots from callus.

\section{Total phenol}

The data on total phenol content revealed significant effects with different method of propagation (Table 1). Among different methods of propagation, graft with Moolanur Moringa rootstocks and annual Moringa cv.PKM 1 scion (T3) recorded lowest total phenol content of $27.70 \mathrm{mg} \mathrm{g}^{-1}$ followed by graft with of Karumbu Moringaroot stocks and annual Moringa cv.PKM 1 scion (T4) with of $28.57 \mathrm{mg}$ g-1. Highest total phenol content was recorded in limb cuttings (T1) of annual Moringa with $42.58 \mathrm{mg} \mathrm{g}^{-1}$

\section{Peroxidase}

Significant differences were noticed for peroxidase activity in the planting materials of different propagation methods (Table 1). The highest peroxidase activity of $0.42 \mathrm{mg} \mathrm{g}^{-1}$ was observed in the Moringa grafts with Moolanur Moringa rootstock and annual Moringa cv.PKM 1 scion (T3) followed by graft with Karumbu Moringa rootstock with annual Moringa cv. PKM 1 scion with 0.37 $\mathrm{mg} \mathrm{g}^{-1}$ (T4). The lowest peroxidase activity of $0.23 \mathrm{mg} \mathrm{g}^{-1}$ was recorded in limb cutting (T1). This is in line with the findings of Nieves et al., (2004) who studied the structural development of graft union formation in tomato plants with positive relationship with the activities of peroxidase and reported that success of graft union is coincided with an increase of peroxidase activity.

\section{Catalase}

Significant difference was noticed for catalase activity due to different method of propagation (Table 1). In the methods of propagation, Moolanur Moringa rootstock grafted with annual Moringa cv. PKM 1 scion (T3) recorded highest catalase activity of 0.23 $\mu \mathrm{g}$ of $\mathrm{H}_{2} \mathrm{O}_{2} \mathrm{~g}^{-1} \mathrm{~min}^{-1}$ than other methods of propagation. Lowest catalase activity was recorded in limb cutting method of propagation (T1) with $0.13 \mu \mathrm{g} \mathrm{H}_{2} \mathrm{O}_{2} \mathrm{~g}^{-1} \mathrm{~min}^{-1}$. Nieves et al., (2004) confirmed increased activity of catalase in the graft union involving cellular defence against the high level of production of $\mathrm{H}_{2} \mathrm{O}_{2}$ in the graft union during curing stage. 
Table.1 Effect of methods of propagation on OD phenol content, total phenol, peroxidase activity, catalase activity in planting materials

\begin{tabular}{|c|c|c|c|c|}
\hline Treatment & $\begin{array}{c}\text { OD phenol } \\
\text { content }\left(\mathrm{mg} \mathrm{g}^{-1}\right)\end{array}$ & $\begin{array}{l}\text { Total phenol } \\
\text { content }\left(\mathrm{mg} \mathrm{g}^{-1}\right)\end{array}$ & $\begin{array}{c}\text { Peroxidase } \\
\text { activity (mg } \\
\left.\mathrm{g}^{-1}\right)\end{array}$ & $\begin{array}{c}\text { Catalase activity } \\
\left(\mu \mathrm{g} \mathrm{of} \mathrm{H}_{2} \mathrm{O}_{2} \mathrm{~g}^{-1}\right. \\
\left.\text { min }^{-1}\right)\end{array}$ \\
\hline $\begin{array}{l}\mathrm{T}_{1} \text { - Limb cuttings of annual } \\
\text { Moringa cv. PKM } 1\end{array}$ & 4.45 & 42.58 & 0.23 & 0.13 \\
\hline $\begin{array}{l}\mathrm{T}_{2} \text { - Air layerings of annual } \\
\text { Moringa cv. PKM } 1\end{array}$ & 3.66 & 37.96 & 0.33 & 0.17 \\
\hline $\begin{array}{l}\mathrm{T}_{3} \text { - Graft with Moolanur } \\
\text { Moringa rootstock and annual } \\
\text { Moringa cv. PKM } 1 \text { scion }\end{array}$ & 2.68 & 27.70 & 0.42 & 0.23 \\
\hline $\begin{array}{l}\mathrm{T}_{4}-\text { Graft with Karumbu } \\
\text { Moringa rootstock and annual } \\
\text { Moringa cv. PKM } 1 \text { scion }\end{array}$ & 2.82 & 28.57 & 0.37 & 0.20 \\
\hline $\begin{array}{l}\mathrm{T}_{5} \text { - Seedlings of annual } \\
\text { Moringa cv. PKM } 1\end{array}$ & 3.63 & 30.79 & 0.34 & 0.16 \\
\hline Mean & 3.45 & 33.52 & 0.34 & 0.18 \\
\hline $\mathrm{CD}(0.05)$ & 0.28 & 1.57 & 0.02 & 0.02 \\
\hline SEd & 0.14 & 0.77 & 0.01 & 0.01 \\
\hline
\end{tabular}

Table.2 Effect of methods of propagation on starch content, nitrogen content, starch content, $\mathrm{C} / \mathrm{N}$ ratio in planting materials

\begin{tabular}{|c|c|c|c|c|}
\hline Treatment & $\begin{array}{c}\text { Total } \\
\text { carbohydrate } \\
\text { content }(\%) \\
\end{array}$ & $\begin{array}{c}\text { Total nitrogen } \\
\text { content }(\%)\end{array}$ & $\begin{array}{l}\text { Starch content } \\
\quad\left(\mathrm{mg} \mathrm{g}^{-1}\right)\end{array}$ & $\mathrm{C} / \mathrm{N}$ ratio \\
\hline $\begin{array}{l}\mathrm{T}_{1} \text { - Limb cuttings of annual } \\
\text { Moringa cv. PKM } 1\end{array}$ & 27.81 & 1.66 & 116.00 & 16.77 \\
\hline $\begin{array}{l}\mathrm{T}_{2} \text { - Air layerings of annual } \\
\text { Moring a cv. PKM } 1\end{array}$ & 31.75 & 1.40 & 134.95 & 24.19 \\
\hline $\begin{array}{l}\mathrm{T}_{3} \text { - Graft with Moolanur } \\
\text { Moringa rootstock and } \\
\text { annual Moringa cv. PKM } 1 \\
\text { scion }\end{array}$ & 33.88 & 1.31 & 140.85 & 24.95 \\
\hline $\begin{array}{l}\mathrm{T}_{4} \text { - Graft with Karumbu } \\
\text { Moringa rootstock and } \\
\text { annual Moringa cv. PKM } 1 \\
\text { scion }\end{array}$ & 32.29 & 1.36 & 137.87 & 23.07 \\
\hline $\begin{array}{l}\mathrm{T}_{5} \text { - Seedlings of annual } \\
\text { Moringa cv. PKM } 1\end{array}$ & 31.64 & 1.32 & 120.85 & 23.97 \\
\hline Mean & 31.47 & 1.41 & 130.10 & 22.59 \\
\hline $\mathrm{CD}(0.05)$ & 1.14 & 0.04 & 4.76 & 0.96 \\
\hline SEd & 0.56 & 0.02 & 2.33 & 0.47 \\
\hline
\end{tabular}




\section{Starch}

The results on starch content of planting materials showed significant differences (Table 2). Among the propagation methods, graft with Moolanur Moringa rootstock and annual Moringa cv.PKM 1 scion (T3) showed highest starch content of $140.85 \mathrm{mg} \mathrm{g}^{-1}$ followed by Karumbu Moringa rootstocks grafted with annual Moringa cv.PKM 1 scion (T4) with the starch content of $137.87 \mathrm{mg} \mathrm{g}^{-1}$. The lowest starch content was noticed in limb cuttings (T1) of annual Moringa cv. PKM 1 with $116.00 \mathrm{mg} \mathrm{g}^{-1}$.

\section{Total carbohydrate}

Significant difference in carbohydrate content was observed due to different method of propagation (Table 2). Among different methods of propagation, graft with Moolanur Moringa rootstocks and annual Moringa cv.PKM 1 scion (T3) recorded higher amount of carbohydrate (33.88 per cent) than Karumbu Moringa rootstocks grafted with annual Moringa cv.PKM 1 scion (T4) with 32.29 per cent. The lowest carbohydrate content of 27.81 per cent was recorded in the limb cutting method of propagation (T1). This finding is in conformity with the findings of Aloni et al., (2008) in the grafts with cucurbita rootstock and melon scion. They reported that carbohydrate content of compatible grafts leading to higher success of the better root formation.

\section{Total nitrogen}

There was significant difference among different method of propagation for total nitrogen content (Table 2). Among different method of propagation, Moringa graft with Moolanur Moringa rootstock and annual Moringa cv.PKM 1 scion (T3) recorded lowest amount of nitrogen (1.31 per cent). Karumbu Moringa rootsocks grafted with annual Moringa cv.PKM 1 scion (T4) recorded 1.36 per cent of total nitrogen. The highest nitrogen content of 1.66 per cent was observed in limb cuttings (T1). This is in line with the findings of Mokashi, 1978 who observed low nitrogen in cuttings of grape showed better capacity to root. Hussein (2008) also reported negative correlation of nitrogen with the rooting percentage in Thunbergia grandiflora.

\section{$\mathrm{C} / \mathrm{N}$ ratio}

The carbohydrate/nitrogen ratio differed significantly with the method of propagation (Table 2). Among the different methods of propagation, Moolanur Moringa rootstock grafted with annual Moringa cv.PKM 1 scion (T3) recorded higher ratio of $\mathrm{C} / \mathrm{N}$ ratio with 24.95 followed by graft with Karumbu Moringa rootstock with annual Moringa cv.PKM 1 scion (T4) with $\mathrm{C} / \mathrm{N}$ ratio of 23.07. The lowest ratio was recorded with limb cutting method of propagation (T1) with 16.77. Mokashi (1978) observed that an abundance of soluble carbohydrates in comparison to nitrogenous reserves was significant for rooting. The results of the present study confirm the earlier findings of Mokashi (1978) in grapes. The results indicated that, the rootstock and scion before grafting registered the highest $\mathrm{C} / \mathrm{N}$ ratio and scion recorded higher ratio than rootstock. Gandev (2009) showed the supporting evidence that the highest grafting percentage was recorded with the better quality scion, which contained higher soluble sugars, starch and $\mathrm{C} / \mathrm{N}$ ratio. The $\mathrm{C} / \mathrm{N}$ ratio could be an important factor for rootability, since the value of $\mathrm{C} / \mathrm{N}$ ratio was positively related to the rooting percentage. Although carbohydrate was found to be beneficial for root initiation, a balance between carbohydrate and nitrogen reserves appeared to be better for root development (Sen et al., 1965). Highst C/N ratio might be the reason for highest success of grafting. 
It can be concluded that the performance of graft of annual Moringa cv PKM 1 scion onto Moolanur Moringa rootstock was good on biochemical basis when compared to other vegetative propagation methods.

\section{References}

Aloni, B., R. Cohen, L. Karni, H. Aktas and H. Edelstein. 2008. Hormonal signaling in rootstock-scion interactions. Sci. Hort., 127: 119-126.

Anonymous, 2006. National Horticulture Data Base.

Gandev, S. 2009. Propagation of walnut (Juglans regia L.) under controlled temperature by the methods of omega bench grafting, hot callus and epicotyl grafting. Bulgarian J. Agri. Sci., 15(2): 105-108.

Hess, C.E. 1962. A physiological comparison of rooting in easy and difficult to root cuttings. Proc. Int. Plant Prop. Soc., 12: 265-268.

Hussein, M.M.M. 2008. Studies on rooting and the consequent plant growth on the stem cuttings of Thunbergia grandiflora (Roxb. Ex Rottl.) Roxb. 2- Effect of Indole -3- butyric acid. World J. Agricultural Sci., 4(S): 811-817

Mokashi, A.N, 1978. Studies on the propagation of Thompson Seedless grape by cuttings. M.Sc., Thesis, University of Agricultural Sciences, Bangalore.

Nanda, K. K., 1974. Biochemical basis of adventitious root formation on etiolated stem cuttings. N. Z. J. For. Sci., 4(2): 347-58.

Nieves,F.G, C.Micaela and O. Enrique. 2004. Graft union formation in tomato plants: Peroxidase and Catalase involvement. Annals of Botany, 93: 53-60.

Sen, P.K., S. Sen and R.N. Basu. 1965. Studies on rooting of cuttings: II. Effect of auxin. Indian J. Pl. Physiol., 8: 36-50.

Singh, S.P. 1979. Effect of rooting media and indole -3-butyric acid on root formation in Jasminum sambac cv. 'Motia' semi hardwood cuttings under intermittent mis. Prog. Hort. 11 (2): 49-52.

\section{How to cite this article:}

Priyadharshini, G. and Irene Vethamoni, P. 2017. Response of Biochemical Aspects on the Success of Various Propagation Methods in Annual Moringa cv.PKM1. Int.J.Curr.Microbiol.App.Sci. 6(6): 250-254. doi: https://doi.org/10.20546/ijcmas.2017.606.030 